https://doi.org/10.18778/8088-222-5.09

Marcin Kafar

Michał Rydlewski

\title{
„PRAWDZIWE ZMYŚLENIE” - NIEOCZYWISTE POLA ZNACZEŃ METAFORY LITERACKIEJ
}

\section{Doświadczenie pierwotne albo jak trafiliśmy na Marka Hłaskę}

Marcin KAFAR: Michale, chciałbym rozpoczać nasze spotkanie od przypomnienia nam obu pewnego wątku. Być może pamiętasz, kilka miesięcy temu zadzwoniłem do ciebie, żeby podzielić się wrażeniami po lekturze twojego tekstu pt. Wszyscy jesteśmy wymyśleni (patrz Rydlewski w niniejszym tomie). Czytając ten artykuł zdałem sobie sprawę, że od mojej młodzieńczej, a właściwie dziecięcej fascynacji twórczością Hłaski minęło dobrych kilkadziesiąt lat. Wszystko zaczęło się jeszcze w szkole podstawowej. Miałem tam „szalona” nauczycielkę od j. polskiego, która w trzeciej lub czwartej klasie dawała nam do czytania lektury na miarę szkoły średniej. Ta nauczycielka zauroczona była m.in. twórczościa Marka Hłaski (w większym nawet może stopniu osobowościa Hłaski) i próbowała w nas tę fascynację zaszczepić. Ogólnie rzecz biorąc, powodzenie tych zabiegów było dość marne, ale ja mam osobisty dług wdzięczności u tej nauczycielki, bo $z$ jakichś tajemniczych powodów (teraz wydaja mi się one bardziej zrozumiałe niż wówczas) podjąłem ten Hłaskowski trop. Pamiętam, jak wielkie wrażenie zrobiło na mnie opowiadanie pt. Pierwszy krok w chmurach. Dziś wiem, że chodziło o romantyzm Hłaski, którym mnie zaraził albo nie, nie zaraził, tylko wypowiedział coś, co skrywało się w młodym człowieku i przez niego samego nie umiało być jeszcze nazwane. W wieku 10 lat marzyłem o spełnieniu się w prawdziwej miłości, takiej, która przyjdzie pewnego dnia 
i zostanie $z$ toba do dnia ostatniego. Cudowna sprawa! I Hłasko pięknie o tym mi opowiadał. Brałem te jego opowieści jeden do jednego - to nie było żadne „prawdziwe zmyślenie” - to była najbardziej realna realność, rzeczywistość ostateczna w dosłownym sensie tego słowa. Po Pierwszym kroku $w$ chmurach przyszła pora na czytanie Pięknych dwudziestoletnich i utworów z okresu emigracji: Opowiem wam o Esther, Palcie ryż każdego dnia, Wszyscy byli odwróceni itd. Te teksty przemawiały do mnie; wypełniały je tragiczne historie, złamani życiem bohaterowie, piloci, zdradzeni mężczyźni, no i język - wciągajacy jak sama opowieść jej język. Niewątpliwie, patrząc $z$ dystansu czasowego mogę powiedzieć, że Hłasko formatował duże obszary mojego myślenia, formował mnie intelektualnie i pomagał mi wyobrazić sobie składowe mojej wrażliwości na rzeczywistość. Co ciekawe, do niedawna (do chwili, kiedy kilka lat temu zaczęliśmy nasza przygodę $z$ „prawdziwym myśleniem”) nie kojarzyłem Hłaski $z$ konstrukcja „prawdy zmyślonej”...

Michał RYDLEWSKI: Moje doświadczenie $z$ opowiadaniami oraz powieściami Marka Hłaski było bardzo podobne do twojego, Marcinie. Może $z$ tą różnica, że po raz pierwszy usłyszałem o tym pisarzu od swojego przyjaciela $z$ lat szkolnych, Błażeja Prusa, który z kolei został "zainfekowany" autorem Pieknych dwudziestoletnich przez swojego ojca - Janusza Prusa (nawiasem mówiąc, postaci przypominającej Wuja Józefa z Sowy, córki piekarza). Myślę, że dla mnie kluczem do odczytania Hłaski na tamta chwilę - i znowu zgram się $z$ twoimi odczuciami - był romantyzm, który przywołałeś, ogromna wrażliwość i umiejętność obserwowania świata; od „zawsze” bliskie były mi też Hłaskowskie postacie i ich dylematy. Bardzo lubiłem króciuteńkie opowiadanie Okno. Identyfikowałem się z chłopcem niezgadzającym się na zastana rzeczywistość; o tej rzeczywistości informuje go dorosły, mówiący, iż „Swiat to jest właśnie kilka takich pokoi”. Chłopiec odpowiada z przekora: „To ja jeszcze zobaczę” (Hłasko 1989: 24). To we mnie nadal jest: niezgoda na rzeczywistość i zaciekawienie nieznanym. Kiedy później zacząłem studia antropologiczne i zostałem wyposażony w teoretyczne narzędzia do myślowego komplikowania tego, co pozornie powinno być oczywiste (w tym problematyzowania własnego życia), z Hłaską ciagle, jak się okazało, było mi po drodze. Cieszy mnie, że ostatni etap tej drogi pokonujemy wspólnie, pracując nad tematem „prawdziwego zmyślenia”. 


\section{„Prawdziwe zmyślenie” w perspektywie tego, co "mówione" i tego, co „pisane"}

Michał RYDLEWSKI: W naszych wcześniejszych rozmowach o „prawdziwym zmyśleniu” kilkakrotnie pojawił się wątek oralności i piśmienności, na który niejako naprowadził nas sam Hłasko, mówiacy w Piekknych dwudziestoletnich o najlepszej radzie dla człowieka piszącego, jaka otrzymał od Igora Newerly'ego...

Marcin KAFAR: ...jeśli chcesz napisać dobrą opowieść, to musisz ja najpierw opowiedzieć ${ }^{1}$.

Michał RYDLEWSKI: Tak. Literatura Marka Hłaski, a co za tym idzie także ta jej warstwa, która spleciona jest $z$ idea „prawdziwego zmyślenia" ma, moim zdaniem, poważny związek $z$ opowiadaniem, a mówiąc dokładniej, zarówno $z$ jego treścia, tj. samą opowiadana historia, jak i z procesem opowiadania. Hłasko niewattpliwie „chodzi i opowiada", testuje przy tym na sobie i na swoich słuchaczach przyszłe pomysły literackie, buduje poszczególne sceny, wreszcie odgrywa potencjalnych tekstowych bohaterów; mamy na to empiryczne dowody (Chmielewski 1993: 62-69). Zaryzykowałbym postawienie tezy, że w tym procesie opowiadania, czy też na czas trwania opowiadanej historii, opowiadane treści staja się dla Hłaski realne. Jeśli tak jest faktycznie, to rzecz robi się arcyciekawa, bo to z kolei świadczyłoby o tym, że - i to właśnie pokazuje przypadek Hłaski - człowiek współczesny nie zatracił do końca „naturalnych” w typach kultur o charakterze magiczno-oralnym pewnych specyficznych umiejętności, które można nazwać metamorficznymi (za chwilę odniosę się bliżej to tego pojęcia); dziś natomiast dochodzą one do głosu w wyjatkowych momentach, np. w momentach „wzruszeń" 2 . W tym sensie Marek Hłasko ma rację, gdy w Sowie, córce

${ }^{1}$ Przypominamy Czytelnikowi, iż w oryginale wypowiedź Newerly’ego brzmi: „Jeśli pan chce coś napisać, niech pan o tym opowiada. Wszystkim. To nieważne, czy pana ludzie rozumieja, czy nie. Niech pan mówi; za każdym razem opowiadając, musi pan budować swoją historię od początku do końca; po jakimś czasie zrozumie pan, które elementy sa ważne, a które nie. Chodzi o to, aby pan sam to umiał sobie opowiedzieć" (Hłasko 1994: 26).

${ }^{2}$ To, że pewne utożsamienia i autentyczne przeżywanie fikcji jest możliwe, świadczy jedno ze wspomnień Aleksandra Jackowskiego. We wzruszającym autobiograficznym wyznaniu starego, mądrego człowieka pt. Na skróty. Posłowie, Jackowski (2007: 158) mówi: „Sumuję teraz moje życie. Wspominam ludzi, ilu ich przewinęło się w tym czasie, ile zdarzeń. Jak silne są wczesne doznania. Wielkie, dramatyczne - zamordowano prezydenta Narutowicza. To był dla dziecka wstrząs. 
piekarza pisze - choć może się to wydawać absurdalne $z$ punktu widzenia logiki prawdy i fałszu - iż mógłby opowiadać ludziom o sobie różne historie i nigdy nikogo by nie okłamał ${ }^{3}$.

\section{Marcin KAFAR: Jak to wytłumaczyć?}

Michał RYDLEWSKI: Według mnie w przypadku Hłaski mamy do czynienia $z$ pewnego rodzaju kilkuwymiarowa mutacja oralności i piśmienności. Co więcej, jest to mutacja, która nie tylko w sposób arefleksyjny tworzy on sam, ale też jest to mutacja, która wpływa na niego jako pisarza i jako człowieka - to jest przecież w ostateczności nierozdzielne. Warto dodać, że podobne mutacje zachodziły w różnych typach kultur, np. w XIX-wiecznej kulturze chłopskiej w Polsce (Burszta 1986: 85-97). Jak się okazuje, także obecnie mamy do czynienia $z$ formami praktyk łaczonych, oralno-piśmiennych. Ta mutacja powoduje, że Marek Hłasko przemyśliwuje opowiadana opowieść podążając za radą Newerly'ego, ale jednocześnie jest, staje się tą opowieścią, przyjmuje - paradoksalnie - jednocześnie postawę zdystansowana i postawę zaangażowana. W oryginalnym kontekście kultury magiczno-oralnej nie może być mowy o myśleniu w naszym rozumieniu, tj. o myśleniu, które jest zdystansowanym przyglądaniem się akcji, testowaniem wariantów danych wątków, powtarzaniu ich dla „lepszego” ułożenia opo-

Jeśli dziś nienawidzę Giertycha, endecji - to zapewne nie tylko w wyniku przemyśleń. Kiedyś siedziałem w kawiarni Ujazdowska, kręcono film o Narutowiczu, Śmierć Prezydenta. Usłyszałem werble, alejami posuwał się kondukt. Wybiegłem, wsunąłem się w tłum statystów, wzruszony, ze łzami w oczach, tak jakby to była trumna $z$ moim ojcem. Przeżycia dzieciństwa wróciły. Są we mnie ciąle i pewnie w moich wyborach".

3 „(...) i zapaliwszy papierosa pomyślałem sobie, iż dobrze by było mieć samochód i wyjechać stąd na zawsze, skończywszy z tą idiotką śpiącą na górze i skończywszy ze wszystkimi tutaj, pojechać tam, gdzie żyją ludzie śródziemnomorscy: ciemnowłosi, cienko kostni i cwani. Tam żyć i tam jeździć samochodem $z$ jednego miasta do drugiego; wciąż jednak brzegiem morza, aby wieczorami czuć zapach soli, ryb i zapach smoły idacy od przewróconych dnem do góry łodzi. I jeszcze czuć zapach tanich kobiet i zmęczonych praca mężczyzn; i tam pić z nimi piwo i wino, i opowiadać im o sobie zmyślone rzeczy i zmyślać dalej w trakcie rozmowy. I byłbym radzieckim lotnikiem, który uciekł w Korei do Amerykanów; ale o trzy kilometry dalej byłbym synem milionera $z$ Teksasu wyklętym przez ojca, $z$ którego druga żona gorszacy dla całego miasta miałem romans; i mówiłbym im, iż potrzebny mi rewolwer, aby skończyć ze soba, gdyż mam raka i porzuciła mnie żona; lecz trzy kilometry dalej byłbym człowiekiem pracujaccym dla firmy filmowej i szukałbym najładniejszej dziewczyny, aby uczynić z niej gwiazdę; i nie skłamałbym nigdy i nikomu. Dano ci życie, które jest tylko opowieścią; ale to już twoja sprawa, jak ty ją opowiesz i czy umrzesz pełen dni" (Hłasko 1993a: 125-126). 
wieści. Wynika to $z$ faktu, że postawa dystansu rodzi się dopiero dzięki pismu. U Hłaski opowiadanie danej historii pozwala mu na dokonanie później literackiego szlifu, ale $z$ drugiej strony - jeśli „na serio" potraktować to, co mówi Hłasko - dochodzi u niego do czasowego utożsamienia się $z$ odgrywana postacia (,.. bo ja sam często bywałem Bogartem"). To specyficzne zanurzenie się Hłaski w opowieści wywołuje umiejętność splecenia się $z$ wybranymi postaciami, który to proces, w moim przekonaniu, jest jednak czymś więcej niż tylko odgrywaniem roli „bycia kimś innym”. Zachodzi tutaj trudno uchwytna bliskość tego, kto jest odgrywany i tego, kto odgrywa. Hłasko wydaje się rzeczywiście przejmować, metamorficznie inkarnować, jak byśmy to ujęli używając teoretycznego języka, od określonych postaci, znanych mu $z$ ekranu i z życia to, co jest mu potrzebne. I to jako pisarz i jako człowiek. Matka Hłaski mówiła, że „z każdego poznanego człowieka, który Marka zainteresował, zafascynował, brał (...) wszystko to, co go interesowało. Osobowość, przeżycia, najcenniejsze wartości" (Śmierć samotnego...). Widać więc wyraźnie, że zakorzenienie w oralności warunkuje u Hłaski upodobania do metamorficznego sposobu bycia.

Osadzenie w oralności, bycie po stronie opowieści ma jeszcze jedną konsekwencję, zazębiająca się $z$ tą, która pokrótce omówiłem. Chodzi mianowicie o osobliwy stosunek Hłaski do poruszanych przeze mnie w moim artykule (por. Rydlewski w niniejszym tomie: 127-136) kategorii prawdy i fałszu oraz fikcji i rzeczywistości. Motyw ten - w skrócie nazwę go „życiem opowieścią" - pojawia się w wywiadzie $z$ matką Marka Hłaski, Marią Hłasko, która przybliża efekty posługiwania się przez młodego pisarza wyobraźnią. Komentując przywołany przeze mnie cytat z Sowy, córki piekarza ${ }^{4}$, Maria Hłasko mówi: „Cytat ów znajduje swój odpowiednik w życiu. Pewnego dnia przyszedł do mieszkania, w którym teraz rozmawiamy, i zaczą mi opowiadać o tym, co widział w mieście. Wyszedł $z$ domu na piętnaście minut, opowieść zaś trwała blisko godzinę. Marek, który do końca się nie zakłamywał, na mój zarzut, że łże, krótko rzekł: "Powiedz, mogłoby tak być?». Mogło, to fakt, ale wcale nie oznacza, że było" (Śmierć samotnego...). Interesujace jest to, że Marek Hłasko - trochę wbrew opinii matki - zakładał, że jeśli coś mogło się zdarzyć („mogło tak być”), to było. $Z$ pewnością okazywało się to użyteczne dla wykształcania „prawdziwego zmyślenia” jako funkcji literatury, co świetnie widać m.in. we fragmentach Pięknych dwudziestoletnich poświęconych opowiadaniu pt. Cmenta-

\footnotetext{
${ }^{4}$ Zob. przyp. 3.
} 
rze. Przychodzi mi także na myśl bardzo długi i ogromnie znaczący fragment z Sowy, córki piekarza, w którym autor-narrator-bohater-którego nigdy realnie nie było, opowiada o swojej rodzinie, młodości bez dziewczyny i swoim pierwszym razie $z$ prostytutka (Hłasko 1993a: 36-42). Jest tam takie sformułowanie nawiązujące do tego, co określiłbym mianem tego, „jak to powinno być”, tj. jak powinna wyglądać sytuacja pierwszego razu, a powinna rozgrywać się w scenerii padajacego deszczu, palonego papierosa, który odrzucany jest niedbałym ruchem, pośród zapachu koszul i śpiewu golacego się człowieka. Hłasko jednak pisze: „(...) i chociaż tak nigdy nie bywa, tak przecież jest naprawdę" (Hłasko 1993a: 37), a w innym miejscu: „(...) i wiedziałem już, że nikt nigdy nie spotkał dziewczyny w deszczu" (Hłasko 1993a: 40). Długo zastanawiałem się nad sensem tych fragmentów i zaczęły być one dla mnie wyjątkowo znaczące dopiero wtedy, kiedy zacząłem je odbierać przez pryzmat „magicznych” inklinacji ich autora. Doszedłem do wniosku, że wyobrażeniowa kreacja, literacki obraz jest w jakiejś mierze prawdziwszy niż życie („i chociaż tak nigdy nie bywa, tak przecież jest naprawdę"), w którym tego typu sytuacje nie mają po prostu miejsca (pierwszy raz wygląda inaczej). Prawdziwe dla Hłaski jest to, co wymyślone, a fakt, że to literatura ma ową zdolność kreacyjna sprawia, iż to właśnie literatura, jako metafora, jako pewien sposób bycia w świecie, jest jedyną rzeczywistą rzeczywistością. I to rzeczywistością, która znajduje się - będę się przy tym upierał - poza prawdą i fałszem ${ }^{5}$.

Marcin KAFAR: Wejdę ci w słowo, Michale, bo wydaje mi się że $\mathrm{w}$ tym względzie trafne intuicje miał inny pisarz, przedstawiciel

${ }^{5}$ Fikcja czy też kłamstwo nie istnieje w kulturze magicznej, gdyż brak tam szeregu opozycji, które zawdzięczamy kulturze filozoficznej, np. prawda - fałsz, rzeczywistość - iluzja, wymysł - empiria (Rydlewski 2015). Tam, gdzie rozmywaja się myślowe struktury binarne, wyobraźnia metamorficzna natychmiast szuka dla siebie ujścia. W odniesieniu do „problemu Hłaski” zasada ta skutkuje zatarciem takich opozycji, jak: tekst - życie, autor - narrator, etc.

Problem braku fikcji, a co za tym idzie kłamstwa sygnalizował chociażby Andrzej Zybertowicz w pracy pt. Przemoc i poznanie (Zybertowicz 1995: 252-257). Zybertowicz, inspirowany teorią kultury Jerzego Kmity, wskazuje, iż pojęcie fikcji jest wynalazkiem kulturowym wynikającym $z$ „odklejenia się" języka od bytu, czyli tego, co wcześniej było nierozerwalne. Powoduje to z kolei powstawanie takich kategorii i dziedzin kulturowych, jak prawda oraz sztuka. Słowem, fikcja nie istniała zawsze, ale jest konstruktem kulturowym, nie w każdej kulturze można zatem kłamać i zmyślać - społeczeństwa bez fikcji, to społeczeństwa znajdujące się poza prawda i poza fałszem. Kłamstwo instytucjonalizuje się i upowszechnia w kulturze zachodnio-europejskiej dopiero w okresie nowożytności, nie było oczywistym jeszcze w średniowieczu (por. Guriewicz 1976). 
współczesnego młodego pokolenia literatów, Szczepan Twardoch. Pytany o motyw autofikcjonalności w kontekście swojej najnowszej książki pt. Wieloryby i ćmy, powiedział, zacytuję: „Pani wie lepiej ode mnie, że takie pytanie zadane autorowi nie ma w zasadzie sensu, bo jeżeli sa [Wieloryby i ćmy - przyp. M.K.] autofikcjonalne, to pania okłamię i powiem, że w ogóle nie sa, że sama prawda, a jeśli nie są, to też powiem, że w ogóle, a może jeśli nie są, to pania okłamię i powiem, że są. Paradoks kłamcy. Ale wracajacc do pani pytania o (...) autofikcjonalność - nie wiem, czy ktokolwiek mógłby odpowiedzieć na nie rzetelnie. Przecież całe nasze życie $z$ bliźnimi budujemy sobie jaźń odzwierciedloną - takich siebie, jakich widzimy w oczach ludzi, których spotykamy. Czy to nie sa zawsze jakoś fikcyjne właśnie narracje, te maski różne, które dla różnych ludzi nakładamy? Może to, co pani tak ładnie nazwała autofikcjonalnością, to tak naprawdę jedyne, co mamy? Może nasza egzystencję określa to, jak samych siebie wymyślimy i opowiemy bliźnim? Jakby człowiek był opowieścią opowiadająca samą siebie... Nie wiem. Może na tym polega bycie człowiekiem. Że samych siebie opowiadamy" (Padol 2015).

Michał RYDLEWSKI: Hłasko wiedział to wcześniej! Wiedział i przetestował ten problem na sobie i to widać w jego tekstach...

Marcin KAFAR: Jeśli jesteśmy przy temacie kultury oralnej, to nie da się pominąć kwestii pamięci. Pamięć jest medium, które pozostaje nieodłączne od tego, co jest związane $z$ opowieścią. Szczególnie ważne było ono w kulturach oralnych, gdzie istniejąca w pamięci zbiorowej święta opowieść konstytuowała cały świat, więcej - opowieść równała się światu (!); świetnie pokazali to w swoich przełomowych pracach Joseph Campbell (1994, 1997, 2004) czy Mircea Eliade $(1966,1998)$. Kiedy w rytuałach odtwarzane były opowieści, jednocześnie odtwarzany był świat, i ten świat się tam urealniał (ty, Michale, nazwałeś ten proces metamorfoza magiczna). To mi się wydaje bardzo istotne także wówczas, gdy mówimy o twórczości, przy czym wchodzimy tu $\mathrm{w}$ obręb specyficznej konstelacji pamięci indywidualnej i zbiorowej oraz tego, co opowiedziane $z$ tym, co napisane. Przyznaję, Hłasko jest modelowym twórca mediującym między tym, co pisane a tym, co opowiadane.

À propos pamięci, przypomina mi się w tej chwili Małgorzata Baranowska, która w poruszającej autobiograficznej książce pt. To jest wasze życie. Być soba $w$ chorobie przewlekłej (2011), wspaniale pokazuje, jak cennym narzędziem pośredniczącym między tym, co doświadczane a tym, co pisane jest pamięć. Ciekawą rzeczą 
u Baranowskiej jest to, jak ona sama siebie obserwuje i uchwytuje proces użyteczności pamięci w reakcji na jakiś ubytek, np. gdy nie jesteś w stanie pisać, tzn. nie jesteś w stanie po prostu wziąć długopisu do ręki, bo ból jest tak nieznośny, że nie pozwala ci utrzymać go w dłoni. Baranowska miała tego rodzaju problem; miewała dni całkowitego wyłączenia $z$ tzw. normalnego funkcjonowania, ale jednocześnie zauważyła, że kiedy nie może pisać, zaczyna komponować obszerne układy myśli, które o dziwo po jakimś czasie była w stanie odtwarzać z pamięci. Później, kiedy atak choroby mijał, te układy myśli zamieniały się w tekst. Dokładnie to samo robił $\mathrm{Hła-}$ sko. Znasz przecież tę znakomitą anegdotę o Hłasce, który otworzył zeszyt i przez 45 minut czytał tekst, którego - co się wkrótce potem okazało - w ogóle tam nie było ${ }^{6}$

Michał RYDLEWSKI: Być może $z$ tej umiejętności „komponowania obszernych układów myśli”, jak to nazywasz, brało się podskórne pobratymstwo Hłaski z pisarzami, którzy wymyślają własne światy? Hłasko wypowiadał się przecież w takim duchu o pisarzach amerykańskich i rosyjskich ${ }^{7}$. Majacc natomiast na uwadze to, co powiedziałem wcześniej, można by faktycznie zejść myślowo niżej, na poziom mitu, świętej opowieści, która przywołałeś. Najczęściej mity jako opowieści to mity o pochodzeniu, o stworzeniu świata lub czegoś innego: człowieka, rzeczy, rośliny, narzędzia. Opowieść rozpatrywana w tym sensie ma dla Hłaski znaczenie mityczne: jest tworzeniem samego siebie, choć oczywiście działa ona na innym materiale kulturowym, tj. takim, który posiada wynalazek jednostki i de facto służy jej autokreacji.

${ }^{6}$ Historia ta należy do gatunku „wędrujących opowieści”. Jedna z jej wersji przywołana jest przez Zofię Hertz, która wspomina: „[Marek - przyp. M.K.] pojechał $z$ naszym znajomym, przyjacielem do jego willi we Włoszech i tam obiecał pisanie nowej książki, którą ma już w głowie. No i jak wrócił po 10 dniach to mówi: "Napisałem już duży kawał książki», a Zygmunt mówi: "No to pokaż coś napisał", on mówi: "Ja ci moge poczytać, jak chcesz, to jest wiesz takie pierwsze tego, to jest, tam sa poprawki». Zaczął czytać i czytał chyba z trzy kwadranse, więc to jednak było sporo i... mówi do Zygmunta: "Zygmunt, jak ci się podoba?», Zygmunt odpowiada: "Doskonałe, tylko kończ jak najszybciej». No i potem Zygmunt powiedział Józiowi Czapskiemu, który mieszkał u nas, Józio zawołał Marka, Marek usiadł i znowu trzy kwadranse mu czytał, a następnego dnia [Marek - przyp. M.K.] pojechał do Paryża, Zygmunt wszedł do jego pokoju, bo tam potrzebna mu była jakaś książka i zobaczył, że leży na stole ten gruby zeszyt, więc go otworzył i tam nie było ani jednego słowa, on to $z$ pamięci przeczytał dwa razy to samo" ( $Z$ nimi żyłem...).

7 „Oni absolutnie nie liczą się z jakass krytyka, taki np. Faulkner to jest pisarz Pan Bóg. Tworząc powieść konstruuje pewien własny świat, własne typy psychiczne, dotąd niespotykane. Takim pisarzem był na pewno Dostojewski” (Bądź wierny sobie...). 
Marcin KAFAR: Pełna zgoda! Nie wolno zapominać, że w dziejach kultury europejskiej jednostka na dobre wchodzi na scenę kulturowa dopiero w wieku XX, a jej formy „samozwrotne”, m.in. zwiazane $z$ literackimi działaniami autokreacyjnymi wzmagają się dopiero na przełomie wieku XX i XXI. Znakomicie przedstawia ten kontekst Roma Sendyka w wydanej niedawno pracy pt. Od kultury ja do kultury siebie. O zwrotnych formach $w$ projektach tożsamościowych (2014).

Wracając jednak do głównego wątku: chciałbym nawiąać do Paula Austera, którego troszkę przyćmił nam Marek Hłasko. Przyglądając się twórczości Austera w trybie autobiograficznym i autokreacyjnym znajdujemy intrygujące rzeczy. Mnie osobiście chyba najbardziej zajmuje tutaj aspekt pisarskiej metodyki posługiwania się imionami bohaterów literackich i tego, jak w tym zakresie Austerowskie postaci inkarnuja różne wymiary Austerowskiego „ja”. Raz jest to „ja” Austera-pisarza, kiedy indziej „ja” pisarza, który nim tylko bywa, jednocześnie jest też tzw. zwykłym człowiekiem; w jeszcze innej sytuacji tekstowej te niejednorodne odsłony „ja” udzielaja sobie nawzajem tożsamościowego wsparcia, podmieniają się, miksuja, ciągna $z$ powrotem do punktu wyjścia, bądź negują albo potwierdzaja siebie - właśnie SIEBIE. Tylko w Nocy wyroczni, którą wziąłem na warsztat na potrzeby naszych rozważań o „prawdziwym zmyśleniu” paleta możliwości jest bardzo szeroka. Np. w świecie literaturoznawczym rozgorzała dyskusja na temat nazwiska „Trause”. „Trause”, jak twierdza niektórzy krytycy, jest akronimem nazwiska „Auster”; zakłada się więc, że ksiażkowy „Trause” pełni funkcję alter ego pisarza, który powołał je do fikcyjnego życia (por. m.in. Bank 2011; Chénetier 1995; Simonsen 2009). Cóż jednak „Trause” ma wspólnego z realnie istniejącym człowiekiem? Z Paulem Austerem $z$ krwi i kości? Dużo, niewiele czy zgoła nic? Takie pytania sa stawiane (por. np. Simonsen 2009). Ja bym się zastanowil, czy takie ujęcie problemu jest w ogóle trafne (choć sam w jakimś stopniu podobnie do niego podszedłem (por. Kafar w niniejszym tomie: 162-163)). Nałożenie odpowiedniego filtra na nasze interpretacyjne okulary bez kłopotu pozwoli nam np. potraktować Trausego jako odbicie Orra, który jest też Orlowskim (czyli Orłowskim), a dopiero ten, okrężną droga, bo poprzez „prawdziwe” koligacje rodzinne (deklarowane przez Austera jego polskie pochodzenie) staje się Austerem-autorem - pisarzem sięgajacym do własnej przeszłości i w oparciu o nią budującym linię narracyjną. Uwierz, że jest to wariant uproszczony autobiograficznego albo quasi-autobiograficznego rysu tożsamościowego, który pojawia się w Nocy wyroczni. W każdej chwili jestem w stanie, bez wielkich 
nadużyć, mocno go skomplikować, wciąż pozostając wiernym intencjom autora. Zresztą, komentarze Austera odnośnie do związków między jego prozą a osobistymi doświadczeniami potwierdzają moje spostrzeżenia ${ }^{8}$.

Jakie konkluzje da się wyprowadzić $z$ tej opowieści? Po pierwsze, dla Austera poziomy fikcji i rzeczywistości pozafikcjonalnej sa równoważne względem siebie. Mało tego: ta równoważność stwarza podstawę do na pozór tylko swobodnego przemieszczania elementów (także tych o charakterze osobistych doświadczeń) między sfera fikcji i prawdy pozafikcjonalnej (zakładając, że również fikcja, co ustaliliśmy dotychczas, jest prawdziwa, choć prawdziwa „inaczej”). Konkluzja druga jest ogólniejszej natury: otóż, tego typu rozstrzygnięcia (nawet na gruncie literatury) są rozstrzygnięciami na miarę współczesności - określonego typu kultury, dopuszczającej istnienie świadomości hybrydalnej, gładko przemieszczającej się między światami o wyjściowo odmiennym statusie ontologicznym.

W Nocy wyroczni sa świetne fragmenty pokazujące, na czym polega "rozmiękczenie” granic między jednym a drugim światem, między rzeczywistością fikcjonalna i niefikcjonalną, ale możliwą do sfikcjonalizowania, przynajmniej potencjalnie. Najbardziej trafiają do mnie passusy przenoszące czytelników w wymiar, w którym czują się oni włączeni w proces twórczy. Przykładowo, Auster ustami Sidneya Orra opowiada o tajnikach pisarstwa, bardzo obrazowo i przekonywająco opisując stan zanurzenia się autora w piśmie. Ważna jest tu sama czynność pisania i ważna jest opowieść, która wciaga pisarza, jednocześnie budując sama siebie ${ }^{9}$. Czy mamy

8 Auster zapytany o swoją najbardziej osobistą książkę, odpowiada: „Najbardziej osobiste sa moje prace non-fiction, dzieła autobiograficzne, ponieważ w nich mówię o sobie wprost. Pośród nich muszę wyróżnić Wynaleźć samotność, jako że jest to moja pierwsza książka napisana prozą. Kiedy pisałem tę książkę byłem dość młody, dopiero co ukończyłem 30 lat, ale mimo to czułem, iż mam podłoże w postaci wszystkiego, co zrobiłem wcześniej. Myślę, że trafnym pytaniem jest, jak opowiadać o innym? W gruncie rzeczy jest to prawie niemożliwe. Jak przeniknąć umysł i duszę drugiego człowieka? Jeszcze bardziej przytłaczające jest pytanie o to, jak przedrzeć się przez własny umysł i własną duszę? Uważam, że jesteśmy dla siebie nieprzejrzyści, i że samowiedza (self-knowledge) jest trudna do osiagnięcia. $Z$ drugiej strony, wszystkie moje nowele bardzo mocno zwiazane sa $z$ moim życiem wewnętrznym; pomimo tego, że wymyślam bohaterów, pomimo tego, że jest to fikcja, pomimo tego, że jest to iluzja, to jednak wyłania się ona $z$ najgłębszych zakamarków mnie" (Big Think interview...; tłum. własne - M.K.).

9 Zdradzając kulisy powstawania Nocy wyroczni Auster przyznaje, iż powieść ta rozwijała się „w sposób niemalże organiczny”, dalej zaś tłumaczy: „Nie byłem pewien dokąd chcę iść, ani co ma się wydarzyć. Miałem w głowie jedynie początek 
tutaj do czynienia $z$ czystą imaginacją? A może ze specyficznym, transowym, jak sugeruje Auster (patrz przyp. 9.), przeżywaniem tekstu, który właśnie jest tworzony? To jest bardzo subtelne i niejednoznaczne doświadczenie. Czy bierzemy udział w jakiejś grze wewnatrztekstowej? Nie do końca, bo jest przecież ktoś, kto jest demiurgiem tego tekstu, a $z$ drugiej strony tekst jest zwrotny, niejako staje w kontrze do autora. No i wreszcie następuje ten zupełnie magiczny moment, gdy tekst i autor staja się jednością. To jest przedziwny stan, który daje się przyrównać, tak myślę, do stanu „przepływu” (flow) w rozumieniu Mihàly Csikszentmihàlyi’a (2005).

Michał RYDLEWSKI: Rozwijasz teraz watek fikcji literackiej jako umożliwiającej wypowiedzenie swojego doświadczenia. Ten wątek pojawił się w twoim artykule, szczególnie w zakończeniu, kiedy przywołujesz Paula Ricoeura (por. Kafar w niniejszym tomie: 169-170). Tego rodzaju problem istnieje w refleksji literaturoznawczej. Inspirująca postacia wydaje mi się pod tym względem chociażby Umberto Eco. Jego zdaniem fikcja fascynuje nas, ponieważ stwarza, jak pisze Eco (1995: 148), „możliwość nieograniczonego wykorzystania naszych umiejętności postrzegania świata i rekonstruowania przeszłości. Fikcja pełni tę sama funkcję co gry. Bawiąc się, dzieci ucza się żyć, ponieważ symuluja sytuacje, w których moga znaleźć się w swoim dorosłym życiu. I poprzez fikcję my, dorośli, ćwiczymy naszą umiejętność organizowania naszego minionego doświadczenia i obecnego doświadczenia. Ale jeśli działalność narracyjna jest tak ściśle powiązana $z$ naszym codziennym życiem, czy nie znaczy to, że interpretujemy życie jak fikcję i że interpretując rzeczywistość wprowadzamy do niej fikcyjne elementy?”. W najogólniejszym sensie, wszystko to, o czym tutaj mówimy, dotyczy „problemu rzeczywistości”. Termin ten zaczerpnąłem $z$ interesującego artykułu Tomasza Markiewki pt. Literatura, rzeczywistość, interpretacja (2012). Markiewka w przejrzysty sposób wypowiada to, co miałem na myśli przy okazji namysłu nad „prawdziwym zmyśleniem" jako sytuującym się poza prawda i fałszem, a co za tym idzie poza innymi opozycjami, takimi jak np. rzeczywistość versus iluzja/kłamstwo. Przy pewnym spojrzeniu literatura okazuje się

opowieści, ale potem, gdy zaczałłem pisać coraz więcej pomysłów przyszło mi do głowy. Po raz pierwszy w strukturze tekstu umieściłem więcej niż jednego narratora, w istocie jest ich trzech. Co jednak chciałem osiagnąć? Nie wiem. Naprawdę nie wiem. Jesteś wciagany w opowieść, bohaterów, język, którym chcesz się posłużyć na danej stronie, a reszta dokonuje się w swoistym transie" (Big Think interview...; tłum. własne - M.K.). 
być integralną częścią rzeczywistości, a nie czymś odrębnym od niej. Starałem się to pokazać w swoim artykule, gdyż ostatecznie fikcyjne postacie wpłynęły na moje życie bardziej, niż postacie realne. To może nawet okazać się niebezpieczne, albowiem czasami bywa i tak, że to nie autor rządzi tekstem, lecz tekst autorem, i to on go kontroluje.

Marcin KAFAR: Zatrzymałbym się przy słowie „kontrolować”. W Nocy wyroczni mamy przecież motyw tego, że tekst zaczyna władać kimś, kto go tworzy. To nawet nie jest kwestia zwrotności w połączeniu $z$ symetrycznością. Tekst zaczyna być kreacją świata w tym sensie, że my zaczynamy nim myśleć i de facto na różne sposoby kształtujemy świat pozatekstowy niejako pod jego wpływem. Tekst przechodzi tym samym w wymiar realnej rzeczywistości i podsuwa nam tropy, które sprawiaja, że to on staje się rzeczywistą rzeczywistością. Być może pod ten problem dałoby się jakoś podciagnać ideę inacted stories, odgrywanych historii (por. m.in. Frank 1997), ale nie do końca... Myślę, że tych wariantów rzeczywistości wychodzącej od tekstu, a nie odwrotnie jest sporo. To ciekawe, jak słowo może stwarzać rzeczywistość, jak ono cały czas powraca i pracuje. O ile znam twoje, Michale, inklinacje teoretyczne, to ty byś pewnie tutaj pomyślał o odległych źródłowo, magicznych mechanizmach kultury...

Michał RYDLEWSKI: Współcześnie kreacyjna moc słowa powraca, ale już w nieco innej postaci niż kiedyś. Być może mamy tu do czynienia $z$ echem magiczno-sakralnej waloryzacji wiązania słów ze światem i skutecznych technik oddziaływania słowem na czytelników, a kiedyś słuchaczy. Należałoby w ogóle przyjrzeć się literaturze pod tym katem, bo choć literatura stoi oczywiście po stronie pisma, to nie jest znowu tak, aby zupełnie wykluczyła określone naleciałości kultury oralno-magicznej, czego odległym pobrzmieniem może być m.in. tak chętne zakładanie przez czytelników paktu autobiograficznego czy innego rodzaju tekstowych paktów ${ }^{10}$; nie

${ }^{10}$ Eco $z$ właściwa sobie dozą ironii opowiada istotna w tym kontekście historię: „Pewien przyjaciel $z$ dzieciństwa, którego nie widziałem od lat, napisał do mnie po wydaniu mojej drugiej powieści, Wahadło Foucaulta: «Drogi Umberto, nie przypominam sobie, żebym kiedykolwiek opowiadał ci tę żałosną historię mojego wujka i ciotki, sądzę jednak, że popełniłeś wielką niedyskrecję, wykorzystując ją w swojej powieści». No cóż, w książce rzeczywiście przytaczam kilka epizodów dotyczących "wujka Karola" i pewnej "ciotki Katarzyny", wujostwa mojego bohatera, Jacopo Belpo, przyznaję, że te postaci naprawdę istniały: dokonawszy kilku zmian, opowiedziałem historię z mojego dzieciństwa dotycząca wujka i ciotki, którzy jednak nazywali się inaczej. W odpowiedzi napisałem przyjacielowi, że Wuj 
bez znaczenia jest również wiara niektórych pisarzy w to, że to, co napisane posiada moc sprawcza - ten wątek pojawia się przecież u Austera, ale nie tylko u niego ${ }^{11} \ldots$

Marcin KAFAR: To nie jest już święta opowieść, która jest światem, ale w dalszym ciagu jest opowieścią, która jednak tworzy świat...

Michał RYDLEWSKI: Zgadzam się.

Marcin KAFAR: Dołożyłbym jeszcze jedną cegiełkę, do tego na razie skromnego domku, który w naszej rozmowie powoli budujemy. Mianowicie: pomyślmy o literaturze, wyrastającej wprost $z$ kultury oralnej...

\section{Michał RYDLEWSKI: Na przykład literaturze chłopskiej...}

Marcin KAFAR: Otóż to! W niektórych odmianach to była literatura, pod która podpisywał się jakiś chłop, a tak naprawdę było to wszystko przeredagowane, bo w surowej postaci nie dałoby się tych tekstów czytać. Jeżeli dzisiaj prowadzisz wywiad z kimś, kto na co dzień pisze, to ten ktoś musi robić korekty samego siebie np. po to, żeby powstający tekst mógł się pojawić w książce, a to jest zaledwie

Karol i Ciotka Katarzyna to moi, a nie jego krewni i że w tej sytuacji to ja jestem właścicielem praw autorskich; nawet nie wiedziałem, że miał wujków i ciotki. Przyjaciel przeprosił: opowieść go tak pochłonęła, że wydawało mu się, że rozpoznaje w niej kilka epizodów z życia swoich krewnych - co nie jest rzeczą niemożliwą, albowiem na wojnie (a do tego właśnie okresu odwoływałem się w swoich wspomnieniach) podobne rzeczy zdarzają się różnym wujkom i ciotkom" (Eco 1995: 14).

$11 \mathrm{~W}$ wywiadzie $z$ brazylijskim pisarzem młodego pokolenia, Danielem Galera, mówi on m.in. o problemach, jakich przysporzyli mu czytelnicy, którzy zaczęli utożsamiać jego fikcyjne historie $z$ nim samym i $z$ rzeczywistymi wydarzeniami. Podejście Galery do kwestii legitymizacji fikcji literackiej poprzez biografię autora zmieniło się chwili, gdy trafił na Czarne plecy czasu Javiera Maríasa, „powieść, w której autor w fascynujący sposób zgłębia kwestię przekształcania osobistych przeżyć w fikcję literacką i późniejszego wpływu fikcji na życie realnych postaci, zwłaszcza samego autora" (Atak na granice... 2011: 342). Galera twierdzi, że na własnej skórze doświadczył podobnych komplikacji przy okazji recepcji Do dnia, $w$ którym zdecht pies, książki, jak mówi, „tylko w niewielkim stopniu autobiograficznej, która po ukazaniu się na rynku zaczęła jakby przenikać do rzeczywistości, odbijając się na moim życiu osobistym serią zbiegów okoliczności, które do dziś nie do końca rozumiem" (Tamże). Wtedy to, mając za inspirację pracę Mariasa, Galera postanowił napisać kolejna książkę, tym razem poświęconą zagadnieniu zacierania granicy między fikcja a „prawdziwym życiem”. Tak oto podsumowuje jej znaczenie: „W rezultacie powieść - według mnie - porusza i komentuje te zagadnienia, nie stawiajac jednak definitywnych tez, poza jedną: nasza interpretacja własnego doświadczenia, które nazywamy "prawdziwym życiem», jest pewna konstrukcją narracyjną, niewiele różniąca się od fikcji literackiej” (Tamże). 
wywiad! Nietrudno sobie wyobrazić sytuację, kiedy mielibyśmy do czynienia $z$ kimś, kto tylko mówi i dodatkowo posługuje się dajmy na to językiem gwarowym, językiem - poza cała swą barwnościa - niezmiernie chropowatym, tak to przynajmniej wygląda $z$ dzisiejszej perspektywy. Przykład pierwszy $z$ brzegu: poeta i prozaik Tadeusz Nowak, autor Półbaśni (1976) i A jak królem, a jak katem będziesz (1968). To był samorodek. Zanim zaczą studiować filologię polska pisał wiersze. To widać w późniejszej twórczości Nowaka. Jego najlepsze teksty, to właśnie te pozostające na granicy świata doświadczanego w horyzoncie chłopskiego żywiołu przy przełożeniu na język, który nie był jeszcze językiem wyszlifowanym, podrasowanym pod kątem obowiąujących w wielkim literackim świecie konwencji. Istnieje szerokie spectrum takich tekstów. To ciekawe, jak teksty moga być różne, w zależności od tego, jak daleko ich autorzy zbliżają się do, bądź jak mocno dystansują się od sfery mówionego.

\section{„Prawdziwe zmyślenie” a problem etyczności}

Marcin KAFAR: Michale, w pierwszych partiach rozmowy obaj przyznaliśmy, że twórczość Hłaski kształtowała nas intelektualnie oraz emocjonalnie. Ja wspomniałem, że brałem teksty Marka Hłaski dosłownie i uczyłem się $z$ nich dookreślania swojej wrażliwości na świat, ty z kolei napomknąeś, iż bliskie były ci „Hłaskowskie postacie i ich dylematy". Myśląc o procesie dialogowania $z$ tą literatura nie dostrzegliśmy w niej żadnego negatywnego wydźwięku, relację ja - tekst potraktowaliśmy jako relację od początku do końca konstruktywną. Po przedyskutowaniu konceptu autokreacji uważam, że tutaj pojawia się jednak pewne niebezpieczeństwo, tzn. nasuwa się pytanie: w jakim zakresie i w jaki sposób ty (przyjmijmy, że tym „ty” jest np. Marek Hłasko), uprawiając autokreację albo po prostu - formujac siebie poprzez pisanie lub opowiadanie jesteś, powinieneś być odpowiedzialny za innego? Chodzi o to, że twoja szeroko rozumiana twórczość nagle może się okazać czymś zdradliwym. $Z$ Bogiem sprawa, gdy to, co robisz, robisz wyłącznie dla siebie, tyle że rzadko mamy do czynienia $z$ sytuacją takiej twórczości (np. powodowane wielorakimi motywacjami pisanie do szuflady mieściłoby się w tym porządku). W momencie jednak, gdy na scenę wchodzi „trzeci element”, czyli czytelnik bądź słuchacz, to ten kontekst zdecydowanie się komplikuje. W filmie Alpy, do którego się odwołujesz w swoim tekście jest ukazana sytuacja, kiedy ktoś mówi: „Ja już 
w tę grę nie gram”. Zacząłem się zastanawiać nad innym jeszcze aspektem sprawy, a mianowicie nad kosztami ponoszonymi przez współuczestników sytuacji czy zdarzeń o charakterze „prawdziwego zmyślenia", nad ceną, jaką nieraz muszą płacić ci, którzy są właśnie tą "trzecią stroną", a więc są słuchaczami lub czytelnikami opowieści (w zależności od tego, do jakiego medium komunikacyjnego się odwołujemy). Nawiązując do Marka Hłaski mówiłeś przed chwilą o „rządzeniu przez tekst autorem”. Ja bym się zastanowił, czy w przypadku niektórych biografii pisarzy nie mamy do czynienia $z$ „pożeraniem” przez opowieści ich autorów (przecież nie tylko Hłasko dał się wciagnąc w wir fikcjonalizacji życia, podobnych przypadków jest wokół co niemiara, vide chociażby Jerzy Kosiński (por. Wróblewski 2012) czy Charles Bukowski, których losy pokazuja, do czego prowadzi życie mitem siebie samego). Odnosząc się do własnego doświadczenia powiedziałeś też coś, co wprost naprowadziło mnie na refleksję dotycząca owego „trzeciego elementu”, powiedziałeś, cytuję, „ostatecznie fikcyjne postacie wpłynęły na moje życie bardziej, niż postacie realne". Tym stwierdzeniem uzmysłowiłeś mi, że potencjalnie wszyscy moga płacić wysoką cenę za uczestniczenie w „prawdziwym zmyśleniu”.

Michał RYDLEWSKI: No tak, jestem pewien, że wszyscy ponosimy jakieś koszty. Mnie w Alpach zainteresowała nasteppująca rzecz: główna bohaterka, pielęgniarka, ale też aktorka podejmująca się w wolnym czasie nietypowych zleceń ma skomplikowane relacje z ojcem; każdego dnia o tej samej godzinie zakrapia mu oczy, obserwuje jego taniec, tyle że oboje sa właściwie obok siebie. Nie ma między nimi silnej więzi itd., właściwie wszystkie sceny, kiedy ona jest $z$ ojcem nie różnią się niczym od scen, kiedy ta bohaterka gra role zmarłych osób, bo to sa te „nietypowe zlecenia”. I teraz co się dzieje? To udawanie (idzie do „normalnej” pracy, później jest aktorką wcielającą się w nieżyjących ludzi), to udawanie nagle obraca się przeciwko niej, bo chce zrobić coś, co doprowadza do zawalenia się jej świata; to się dzieje wtedy, kiedy...

Marcin KAFAR: ...kiedy dotyka ojca w intymny sposób...

Michał RYDLEWSKI: Tak, i tutaj paradoksalnie, bo poprzez udawanie, czyli przez sztuczna konwencję chce dotrzeć do czegoś prawdziwego, ale reakcja ojca jest gwałtowna i zdecydowana: on ją uderza, czyli przekaz z jego strony jest taki: „Ja w to nie gram! Ja nie będę wchodził w tę grę!". Po obejrzeniu Alp nie wiadomo, co to jest „autentyczność”, co to jest „prawdziwa relacja”. Nijak nie da się 
odpowiedzieć na to pytanie. Główna bohaterka chce prawdziwych relacji poprzez udawanie. Dopiero wtedy dochodzi do jej upadku. Ona bardziej woli żyć życiem pożyczonym niż swoim własnym, bo swojego własnego życia de facto nie ma: przychodzi do domu z pracy, śpi, wstaje, i tak w kółko.

Marcin KAFAR: Tak, w tym sensie masz rację. Potwierdzeniem tego, co mówisz jest też scena włamania tej bohaterki do domu rodziców dziewczyny, która aktualnie odgrywa. Rodzice tej dziewczyny siła wyrzucaja aktorkę na zewnątrz; jakby chcieli krzyknąc: „Nas ta gra więcej już nie interesuje! Nas nie interesuje przedstawienie, które nam urządzasz!”.

Michał RYDLEWSKI: Dokładnie tak. Ale zwróć uwagę - ta aktorka nie ma nic poza tym przedstawieniem... Czyli - na innym poziomie - można powiedzieć, że „prawdziwe zmyślenie” musi dziać się wtedy, gdy wszyscy wiemy, że gramy w tę samą grę, znamy reguły tej gry itd.

Marcin KAFAR: Dobrze. Ale tutaj zakładasz, Michale, uaktywnienie świadomości wszystkich stron...

Michał RYDLEWSKI: Pozwól, że dokończę. Otóż zgadzam się z tobą, że ważne jest to, że wszystkie strony muszą...

Marcin KAFAR: Wszystkie strony moga być świadome, albo raczej odwrotnie: nie wszystkie strony moga być świadome tego, w czym biora udział. To $z$ kolei rodzi, przynajmniej potencjalnie, wielkie problemy etyczne.

Michał RYDLEWSKI: Zgadzam się, chodzi o wzięcie odpowiedzialności za to, co robię, wzięcie odpowiedzialności za kogoś, kogo wciaggam $\mathrm{w}$ tę grę.

Marcin KAFAR: Tak. Uważam, że to jest niezwykle istotny problemem w kontekście „prawdziwego zmyślenia”. Wydaje mi się, że wszystko jest w porządku do momentu, gdy każda ze stron bioracych udział w tych aktach rozgrywania "prawdziwego zmyślenia” ma świadomość tego, że to jest „prawdziwe zmyślenie”...

Michał RYDLEWSKI: I się na to godzą...

Marcin KAFAR: I się na to godzą, i gra się toczy dalej; może to być gra autokreacyjna, może też...

Michał RYDLEWSKI: Ale poczekaj, bo tu sa dwa poziomy w teoretycznym sensie; pierwszy poziom związany jest $z$ pytaniem: co się 
dzieje, gdy jeden $z$ uczestników mówi: „Ja już nie gram?”, a drugi poziom zwiazany jest $z$ tym, o czym wspomniałeś, czyli: co się dzieje, gdy wiedza i świadomość tych graczy jest różna?

Marcin KAFAR: No właśnie. To sa kwestie raczej nie do przewidzenia, jeśli idzie o konsekwencje...

Michał RYDLEWSKI: Co do kosztów społecznych, to - pozostając jeszcze przez chwilę przy Alpach - tam się pojawia ważne zdanie, wypowiedziane na początku filmu przez jednego $z$ głównych bohaterów, Mont Blanca; on mówi: „Wybrałem nazwę Alpy, bo Alp nie da się zastąpić, ale Alpy moga zastąpić każde inne góry". To znaczy, że ci samozwańczy aktorzy, bo oni stanowia grupę samozwańczych aktorów, samych siebie podnoszą bardzo wysoko, do rangi nieomal nadludzi, którzy mogą wcielić się w innych, natomiast ich nikt nie zastapi. To jest bałwochwalcze, ale dalsza część filmu w istocie pokazuje, że tak nie jest, że na wiele sposobów jesteśmy niedoskonali. Dla przykładu, główna bohaterka okazuje się być nieprofesjonalna, bo wychodzi poza zaplanowaną wcześniej rolę, czyli, ujmując rzecz za pomoca przenośni, nie należy do tych „Alp”.

Marcin KAFAR: Mhm. Dla mnie interesujące jest to, że ten wątek etyczności nie pojawił się w tekście ani u ciebie, ani u mnie, a teraz, przy włączeniu $\mathrm{w}$ naszą rozmowę kwestii tego „trzeciego elementu", okazuje się być pod wieloma względami ważny. Skoro jesteśmy przy tym tropie, to koniecznie muszę przywołać historię, która według mnie jest niezwykle sugestywna i przez to też instruktywna. Chodzi właściwie o zjawisko, bo sprawa dotyczy czegoś więcej niż tylko opowieści czy literatury i jej związku ze światem pozaliterackim. Od razu zaznaczę, że tę historię odnoszę głównie do filmu dokumentalnego pt. Serce jest zdradliwe, ściślej rzecz ujmujacc, ten film był dla mnie punktem wyjścia do myślenia o etyczności w kontekście „prawdziwego zmyślenia” jako części praktyk kulturowych.

Historia zaczęła się w pierwszej połowie lat 90. XX wieku w Stanach Zjednoczonych, konkretnie w San Francisco. Początek jest bardzo niewinny - do San Francisco przyjeżdża dwójka artystów: Laura Albert i Geoffrey Knoop, którzy postanawiaja założyć grupę rockowa Thistle (Thistle koncertuje także jako Daddy Don't Go). Okazuje się, że zespół ma kłopoty z przebiciem się do głównego nurtu muzycznego i wtedy pojawia się dość szalony pomysł, który, dzięki pewnemu szczególnemu zbiegowi okoliczności, szybko uruchamia ciagg nieprawdopodobnych zdarzeń o wielkim społeczno- 
-kulturowym zasięgu oddziaływania. Zrekonstruuję je w możliwie wielkim skrócie: Laura spotyka na ulicach San Francisco kilkunastoletniego chłopca; ten chłopiec nie ma rodziny i wygląda na mocno pogubionego. Jeremy (Jeremiah), bo tak ma na imię nowy znajomy Knoopa i Albert, trafia do ich domu. Późniejsza, oficjalna wersja wypadków mówi o tym, że na Jeremy'ego natknęła się niejaka Speedie vel Emily Frasier, pracownik socjalny pomagajacca biedakom mieszkajacym na ulicy i to ona, razem ze swoim partnerem, niejakim Astorem, postanowiła zaopiekować się Jeremym. Wieść niosła, że Speedie i Astor, martwiąc się o stan psychiki nastolatka wysyłali go na konsultacje terapeutyczne do zaprzyjaźnionego psychoanalityka, a ten poradził dzieciakowi, by opisał swoje przeżycia. Okazało się, że Jeremy ma nieprzeciętny talent pisarski. Poznają się na nim $\mathrm{m}$.in. ceniony poeta i performer Dennis Cooper i Bruce Benderson, pisarz blisko zwiazany $z$ awangarda nowojorska. Cooper i Benderson sa do tego stopnia pod wrażeniem twórczości „dzieciaka $z$ ulicy”, że postanawiają skontaktować go $z$ wydawcami, którzy błyskawicznie zawieraja $z$ Jeremym umowę na wydanie autobiograficznej powieści. Pierwsza książka Jeremy'ego pt. Baby doll pojawia się w 1997 roku, druga - Sarah wychodzi w roku 2000 i od razu powoduje spora woltę w świecie amerykańskiej bohemy literackiej, staje się też głośna wśród szerszej publiczności. Czytelników zaskakuje dojrzałość warsztatu pisarskiego Jeremy'ego (on sam o sobie mówi „J.T. LeRoy” (skrót od „Jeremiah Terminator LeRoy”) albo, częściej, po prostu "Terminator” - taki przydomek nosił ponoć, gdy „przynależał” do ulicy); zaskakująca jest też, o ile tak można powiedzieć, niewspółmierność wieku LeRoya do sposobu pisania i tego, czego to pisanie dotyczyło (J.T. pisał m.in. o tym, co działo się $z$ nim zanim trafił do San Francisco; dowiadujemy się, że tułał się $z$ matka, która była prostytutka po południowych Stanach Ameryki i że był przez nią poniżany, nakłaniany do brania narkotyków i sprzedawania się kierowcom ciężarówek). Tak czy inaczej, J.T. robi błyskawiczną karierę. W 2001 roku wychodzi jego trzecia ksiażka (zbiór nowel pt. The heart is deceitful of above all things), pojawiaja się też propozycje zrobienia o nim filmu, sztuki teatralnej itd. Krótko mówiąc - machina medialna na dobre się rozkręca. Co ciekawe, J.T. jak ogna unika publicznych wystąpień, nawet fragmenty jego publikacji czytają za niego inni (m.in. w rolę zastępcy J.T. decyduja się wejść jego pierwsi promotorzy, czyli Benderson i Cooper). W którymś momencie J.T. jednak wychodzi $z$ cienia, chociaż cały czas jest wycofany. Nie udziela wywiadów twarzą w twarz, zachowuje się mocno socjopatycznie 
(np. potrafi omdleć w trakcie normalnej rozmowy, bo jest ona dla niego zbyt „dużym wyzwaniem emocjonalnym”). Tego rodzaju zachowania $\mathrm{w}$ powiązaniu $z$ nieprzeciętna erudycją J.T. wzbudzaja wątpliwości u paru dociekliwych dziennikarzy; podejrzewaja oni że J.T. nie jest tym, za kogo się podaje. W gronie tych nieufnych dziennikarzy na pierwszym planie jest Stephen Beachy, dziennikarz z Nowego Jorku, który po kilku latach zbierania materiałów ostatecznie dociera do drugiego dna zjawiska, jakim jest „J.T. LeRoy". W demaskatorskim artykule pt. Who is the real JT LeRoy? A serach for the true identity of a great literary hustler Beachy stawia obrazoburcza dla wielu tezę, że J.T. nie istnieje, że tak naprawdę jest on wielka mistyfikacją. Zdaniem Beachy'ego, J.T. to konstrukt wymyślony przez Laurę Albert, konstrukt, który angażuje wiele osób począwszy od samej Albert, poprzez jej męża, Geoffreya Knoopa (to on był pierwowzorem postaci Astora), siostrę Knoopa, Savannę Knoop ${ }^{12}$ (odgrywała ona rolę LeRoya, przebierając się za niego i występując publicznie jako rzekomy J.T.), innych członków rodziny i znajomych Geoffreya i Laury (służących np. za postacie-słupy pobierajace tantiemy autorskie albo użyczających własnych numerów telefonów do prowadzenia przez fikcyjnego J.T. rozmów z dziennikarzami itd.), kończąc zaś na czytelnikach prozy LeRoya, nie mających pojęcia o tym, że biora udział w grze, której reguł po prostu nie znaja.

Pominę opis przeciekawych skądinąd perypetii, w jakich uczestnicza obie strony „przekrętu” w kolejnych jego odsłonach. Chciałbym natomiast zwrócić uwagę na reakcje tych, którzy poczuli się najbardziej dotknięci przez Laurę Albert, kiedy kurtyna pierwszego aktu wymyślonego przez nia przedstawienia „J.T. Le Roy” opadła. Te reakcje sa uderzające. Dla przykładu, Bruce Benderson zwierza się: „To było surrealne doświadczenie. [J.T. - przyp. M.K.] wydawał mi się tak realny, że MUSIAŁ istnieć. Nie dowierzałem, później byłem rozgoryczony, a jeszcze później zły" (Serce...); w jednym $z$ rozpaczliwych maili do J.T. Benderson wręcz błaga go o zdementowanie krążaccych pogłosek o jego fikcyjności, bo jeśli te okażą się prawdą to, jak mówi, „spora część mojego świata się zawali” - „nie

12 Savannah mocno uzależnia się od odgrywania postaci J.T., co widać m.in. w następującej wypowiedzi: „Nie umiałabym się z nim pożegnać, nie wiem, czym było by moje życie bez J.T.” (Serce...). O wchodzeniu w rolę „J.T.” i cenie, jaka przyszło za to zapłacić traktuje memuar pt. Girl boy girl. How I became JT Leroy (Knoop 2008). 
otrzymałem odpowiedzi" - przyznaje (Tamże) ${ }^{13}$. W innej wypowiedzi Benderson zwraca się wprost do Albert i oskarża ją o niegodziwość ocierajaca się o sadyzm: „Nie dbam o to, że wybiłaś się okłamujacc mnie, najgorsze jest to, że zmanipulowałaś mnie bez wyraźnego powodu, a skoro powodu nie było, postrzegam to jako sadyzm" (Tamże). Dennis Cooper stwierdza natomiast: „Wykorzystywała nas, zadręczała i nagabywała (...). Jest utalentowana pisarka, ale znacznie lepszym kłamca” (Tamże). Z kolei Stephen Beachy rzucając: „Ekstrema mnie pociagaja”, zastanawia się: „Gdzie sa granice kłamstwa i gdzie jest jej prawdziwe ja?” (Tamże). Laura Albert odpowiada mu bardzo przewrotnie: „Może jestem Astorem i Speedie, a może amalgamatem uniwersalnej świadomości” (Beachy 2005; tłum. własne - M.K.).

Michał RYDLEWSKI: Wydaje mi się, że dopiero po wysłuchaniu tej historii do końca rozumiem, Marcinie, o co ci chodziło, kiedy mówiłeś o tym „trzecim elemencie”. Nie wiem, czy to nie jest tak, że każdy, kto zaczyna „bawić się” w „prawdziwe zmyślenie” i wciaga w tę zabawę innych - nieważne czy robi to $z$ rozmysłem, czy nie - naraża tych ludzi na różnego typu straty moralne. Jeszcze raz powrócę do tego, co mówiła Maria Hłasko o swoim synu, wcześniej powoływałem się na jej wypowiedź, ale ta wypowiedź jest bardziej obszerna, ona mówiła, że Hłasko miał niewielu przyjaciół, co wynikało $z$, cytuję, „jego bardzo nieprzyjemnej cechy charakteru: $z$ każdego poznanego człowieka, który Marka zainteresował, zafascynował, brał - i to w sposób bezwzględny - wszystko to, co go interesowało. Osobowość, przeżycia, najcenniejsze wartości. Później ten ktoś był mu już niepotrzebny. Ludzie ci wciaż przychodzili, szukali kontaktu, było mi wstyd za Marka, lecz nie mogłam nic zrobić" (Śmierć samotnego...).

Marcin KAFAR: „Prawdziwe zmyślenie” traktowane jako gra czerpiąca, że się tak wyrażę, $z$ repertuaru możliwości, jakie podsuwa

${ }^{13}$ Benderson usilnie wzbraniał się przez koniecznością uznania J.T. za figurę wyobraźni. W związku z tym, po ukazaniu się tekstu pt. Who is the real JT LeRoy?, dawał taką oto ripostę Stephenowi Beachy'emu: „Po opublikowaniu książki nikt nie jest w stanie udowodnić, że jej autorem jest LeRoy. Podobnie, któż skłonny byłby powiedzieć, że Stephen Beachy naprawdę napisał ten artykuł? Gdzie jest na to dowód?" (Benderson 2005; tłum. własne - M.K.). Warto nadmienić, że w początkowym okresie znajomości J.T. traktował Bendersona jako swego powiernika. Obaj prowadzili wielogodzinne rozmowy telefoniczne nie tylko o twórczości, ale też, przede wszystkim, o traumatycznych doświadczeniach LeRoya. To zapewne $z$ tego powodu zrozpaczony Bruce Benderson wyzna potem: „(..) czuję się poraniony, straciłem bliskiego przyjaciela" (Serce...). 
ci świat (w obrębie tych możliwości mieszczą się też relacje $z$ drugim człowiekiem) jest mieczem obosiecznym. Nie sądzę, żeby Hłasko celowo porzucał swoich znajomych. Raczej do głosu dochodziła specyficzna hierarchia wartości, choć ona też może być poddana ocenie. Skoro na pierwszym miejscu była literatura, wszystko (i jak się okazuje wszyscy) co do niej prowadziło musiało w jakimś sensie mieć charakter instrumentalny. Ci ludzie, którzy byli zawiedzeni postawa Marka, prawdopodobnie oczekiwali po kontakcie z nim zupełnie czego innego niż on sam. Trochę na zasadzie: „Ja jako pisarz gram $\mathrm{z}$ tobą $\mathrm{w}$ przyjaźń, ty jako człowiek chcesz się spełniać w Przyjaźni ze mna”. To nie znaczy, że Hłasko nie miał prawdziwych przyjaciół (choć i ich mimowolnie wplątywał w akcje „prawdziwego zmyślenia"). Pamiętasz przecież, dalej w tej samej wypowiedzi, która zacytowałeś, Maria Hłasko mówi: „Jedną $z$ niewielu osób, które naprawdę uwielbiał, był mąż mojej siostry. Bardzo go lubił - do tego stopnia, że będąc w USA i mając przy sobie jego powiększony portret Marek wmawiał ludziom, że jest to jego brat" (Tamże).

Pozwól, że wróce jeszcze na chwilę do postaci J.T. Na pytanie kogoś z bliskiego otoczenia Laury Albert, dlaczego lekceważyła ona uczucia innych osób, odpowiedziała, mając na myśli siebie: „Pomagaliście komuś, żałujecie tego?”. Integralnym wymiarem „prawdziwego zmyślenia" w wydaniu Albert było radzenie sobie $z$ demonami trudnej przeszłości. Przeczuwam, że mamy tutaj do czynienia $z$ jakimś ogromnym paradoksem i wynikajaca $z$ niego ambiwalencja postaw. Podjęcie próby „przepracowania” osobistego dramatu za pomoca sztuki (literatury i niejawnego performansu), w przypadku Laury Albert doprowadziło do ranienia - i bezpośrednio, i pośrednio - wielu osób. Albert oburza się, że po ujawnieniu kulisów jej zmyślonych działań w „New York Times” nazwano ja „fikcyjnym autorem fikcji" (fake fiction writer); na swoje usprawiedliwienie powtarza za Oscarem Wilde'em: „Daj człowiekowi maskę, a powie ci prawdę" (Serce...). Gdyby Albert zacytowała jeszcze zdanie poprzedzające to, którym się posłużyła, a brzmi ono: „Man is least himself when he talks in his own person" ("Człowiek najmniej jest soba wtedy, gdy mówi we własnej osobie" (Wilde 1997 [1913]); tłum. własne - M.K.), to Wilde spokojnie zasłużyłby na miano jej „duchowego patrona".

Wiele problemów się tutaj nawarstwia i na pewno nie sa one jednoznaczne pod względem etycznym. Pamiętasz przecież dylematy samego Wilde'a, bodaj najwyraźniej wypowiedziane w Portrecie Doriana Graya. Na poziom wolności uprawiania sztuki nakłada się tam poziom rozstępu życia ukrytego za obrazem tego, kto tę sztu- 
kę podejmuje i czyni sensem swoich codziennych działań. Tyle że historia Graya kończy się tragicznie. Prawdziwe życie ostatecznie bierze górę nad sztuka, okazuje się, że los człowieka jest do cna przesiąknięty skończonością, i to skończonością wieszcząca jego upadek. Historia Laury Albert jest niezwykle przewrotna. Albert $z$ jednej strony przypomina Graya (szczególnie, gdy przywdziewa maskę J.T. - na zewnątrz to blond młodzieniec, o niewinnej, androgenicznej twarzy, wewnattrz - skomplikowany, ambiwalentny charakter, bliski kulturowej figurze trickstera), $z$ drugiej wydaje się umieć go przekraczać. Wyjście na jaw przekrętu pod hasłem J.T. LeRoy jest niczym, posługując się przenośnią, wbicie przez Graya noża we własny portret. Obnażone występki pokazuja „prawdziwe" twarze tych, którzy się ich dopuszczają. Na tym jednak historia się nie kończy. Okazuje się, że kończy się tylko jej pierwsza odsłona. Kolejna wiąże się np. ze zdobyciem przez Albert nowych fanów, którzy uznali jej wyczyn za godny największego artystycznego uznania (nawiązując m.in. do praktyk Warholowskich). Albert nie waha się wykorzystać tej fali ponownego zainteresowania jej twórczościa, przypisuje nawet swojej literaturze wartość terapeutyczna w odniesieniu do szerokiego grona czytelników: „Fani wrócili, ludzie opisywali, jakie wrażenie zrobiły na nich moje dzieła, jak ich odmieniły, jak ocaliły ich życie" - opowiada (Serce...).

Nic dodać, nic ująć.

\section{Poza „prawdziwe zmyślenie”}

Marcin KAFAR: Michale, w którymś momencie naszej dzisiejszej rozmowy wypowiedziałeś następujące zdanie: „Prawdziwe dla Hłaski jest to, co wymyślone, a fakt, że to literatura ma owa zdolność kreacyjna sprawia, iż to właśnie literatura, jako metafora, jako pewien sposób bycia w świecie, jest jedyna rzeczywistą rzeczywistością" Ja mam tutaj sporo wątpliwości. Tzn. wydaje mi się, że takie postawienie sprawy mocno upraszcza, redukuje tożsamościowo nie tylko Marka Hłaskę, ale i nas wszystkich, mających w sobie wiarę, że prawda o życiu nie wyczerpuje się w horyzoncie "prawdziwego zmyślenia”. Twardoch, wypowiadając się w nieco Goffmanowskim stylu sugeruje, że człowiek ściaga maskę, by ukazać twarz... przykryta kolejna maska. Historia o J.T. jest pod tym względem wstrzassająca. Rodzi ból, nie zostawiając nadziei na wyjście $z$ matni gry. Pod płaszczykiem uprawiania sztuki dzieja 
się rzeczy okrutne. Człowiek zamienia się w istotę pozbawioną fundamentalnych referencji aksjologicznych. Sądzę, niestety, że współczesny świat (nie znoszę tego rodzaju uogólnień, ale tym razem wyjątkowo sa one chyba uzasadnione) sprzyja przyjmowaniu takich skrajnych jednowymiarowych postaw. Osobiście na to się nie godzę, $\mathrm{i}$ - wypowiadając się $z$ pozycji zaangażowanego depozytariusza kultury - nie uważam, że godził się na to Marek Hłasko. Uzasadnię swoje przekonanie w prosty sposób. Otóż, jeśli byśmy patrzyli na Hłaskę wyłącznie jako na pisarza, to być może tego rodzaju argumentacja, jaka tutaj proponuję byłaby chybiona. Faktycznie, Hłasko jako pisarz obiema nogami stoi po stronie „prawdziwego zmyślenia”, ale Hłasko nie jest wyłącznie pisarzem, jak sam powiedziałeś podnosząc kwestię oralności i piśmienności - jest także człowiekiem. Nie chciałbym, żeby zabrzmiało to zbyt patetycznie, nie taka mam intencję, ale to bycie człowiekiem rozumiane jako sięganie do wartości zasadniczych, nie podlegających kwestionowaniu jest rysem bardzo charakterystycznym u Marka Hłaski; mało tego, jest to rys wyraźnie udokumentowany m.in. na piśmie, choć to pismo paratekstualne, przyjmujące formę epistolarna. Jak widzisz, trochę inaczej niż ty rozumiem więc kwestię istnienia poza prawda i poza fałszem. Nota bene bliski temu wątek odnalazłem również u Paula Austera, choć $z$ paru względów nie chciałbym wchodzić w tym miejscu w kontekst Austerowski, zostawię ten temat do rozwinięcia przy innej okazji.

Michał RYDLEWSKI: Myślę, że to podejście wynika $z$ twoich zainteresowań naukowych, tego, czego poszukujesz oraz tego, kim jesteś. Mnie bardziej zaintrygowało samo „prawdziwe zmyślenie” jako metafora, niż to, co jest poza nią. Ty, Marcinie, pewnie byś powiedział, że poza nia jest życie. Różnica pomiędzy nami polega na tym, iż mnie Hłasko interesował właśnie jako pisarz, jak to wcześniej określiłeś, choć oczywiście to bycie pisarzem pozostaje w związku $z$ byciem człowiekiem. Ale zgadzam się $z$ toba, że - by jakoś to ująć, przy okazji nie gubiąc ważnych subtelności - nie $z$ całym człowiekiem. W tym sensie jest uprawnione dopytywanie: co poza "prawdziwym zmyśleniem"? Wystarczy poczytać wspomniane przez ciebie listy Hłaski, żeby się o tym przekonać. Te listy, czy właściwie ich fragmenty, które ja znam, a które np. przywołuje w swojej książce pt. Miłosne gry Marka Hłaski Barbara Stanisławczyk (1998), pokazują innego Marka Hłaskę, inną stronę jego tożsamości, niż ta wspierająca się o „prawdziwe zmyślenie”. Podam dwa przykłady, które w różnych aspektach obrazują chyba twoje intuicje. 
Pierwszy to opis, który wstrząsną Sonią Ziemann (żoną pisarza). Opis ten przedstawia Marka Hłaskę na dwa miesiące przed jego śmiercią. Razem z Sonia „Byli w starej Jerozolimie (...). Na prośbę Marka szli via Dolorosa. Na każdej stacji żegnał się i szeptał modlitwę. Poszli do Bazyliki Grobu. Modlili się w Grocie Złożenia Ciała. Nie chciał stamtąd odejść. Klęczał, oparł głowę o marmurowa płytę Grobu, płakał. Modlił się półgłosem, czasem był to jęk, chylił głowę, bił się w piersi, łzy ściekały mu na policzki i usta" (Stanisławczyk 1998: 71-73). Wątki religijne sa obecne w twórczości Hłaski, co jednak zasługiwałoby na osobne omówienie. Przywołam tylko jeden, znaczący jak sądzę ustęp z Drugiego zabicia psa. W zakończeniu, kiedy to oszukana kobieta, Mary, dla której Robert i Jakub „odstawili” teatr, odjeżdża, czytamy: „Znałem tu wiele miejsc i wielu ludzi. Ale dlaczego nie potrafiłem o tym pisać? Dlaczego potrafiłem to czuć, a nie umiałem o tym mówić - nie wiem. Dlaczego nie powiedziałem i nie napisałem nigdy, iż nie ma większego nieszczęścia jak życie w nieświadomości Boga; jak życie wbrew jego przykazaniom - nie wiem. Dlaczego nie umiałem nigdy powiedzieć, że największym grzechem jest stracenie miłości drugiego człowieka - nie wiem. Może było za goraco, a może po prostu zapomniałem" (Hłasko 1993b: 122).

Jeśli uznać, że mówi tutaj sam Hłasko, i jeśli zestawić obraz jego modlitwy w Jerozolimie $z$ zakończeniem Drugiego zabicia psa, to można by nawet zaryzykować postawienie tezy, że tej części Hłaski, o która tobie chodzi (jako człowieka, a nie jako pisarza) w jego literaturze nie ma. A zatem faktycznie trzeba przyjrzeć się temu, co mówił i o czym pisał poza literatura sensu stricto.

Drugi fragment jest lżejszego kalibru, ale chyba dobrze pokazuje on szczerość relacji, jakich pragnał i jakich poszukiwał Hłasko. Mieszkając w Ameryce Hłasko bardzo ciężko pracował fizycznie; to była praca w fabryce, gdzie zatrudnieni byli głównie Irlandczycy. Od noszenia blachy Hłasce zrobiły się na rękach bąble, a po ich popękaniu - rany. Po otrzymaniu zastrzyku przeciw tężcowi, wystraszył się, że jest uczulony na ten lek. Zadzwonił do Marka Nizińskiego, żeby tamten natychmiast przyjechał go ratować albo towarzyszyć mu w ostatnich chwilach życia. Niziński, razem ze swoją matka, Ewą Krzyżanowską i Zofią Komedowa pojechali do mieszkania Hłaski. „Zanim jednak dojechali - opisuje Barbara Stanisławczyk - Marka już nie było w domu. Niziński na to: "Tu jest niedaleko taki irlandzki pub, na pewno tam go znajdziemy". Przebywanie wśród Irlandczyków było drugim, obok roboczego stroju, wyrazem jego manifestacji. Zwykł mawiać: "Jestem tu pariasem i z pariasami się przyjaźnię". Poszli więc do pubu. Przy okragłym barku stał Marek, pił piwo i śpie- 
wał polskie pieśni. Zapomniał o tężcu. Zofia Komedowa bardzo źle się wtedy czuła, jej mąż walczył o życie. Marek zawołał jednego z Irlandczyków. "Masz jej wymasować kark!" - powiedział, a do Zofii: "Zobaczysz, jak on świetnie to robi». Rzeczywiście masaż przyniósł ulgę, a jeszcze bardziej dwa piwa zmieszane $z$ whisky, które kazał jej wypić. Potem zaczął śpiewać "Chryzantemy złociste", które były modne, kiedy wyjeżdżał z Polski. Irlandczycy odpowiedzieli mu swoja narodowa piosenka, a zebrani w barze orzekli, że irlandzka jest ładniejsza. Zirytowany Hłasko zaśpiewał inna, tamci z kolei swoja i znowu werdykt był po stronie Irlandczyków. W sukurs przyszła mu Zofia Komedowa. Zaśpiewali na dwa głosy ukraińska dumkę ("Na zielonej Ukrainie...") i wygrali" (Stanisławczyk 1998: 39-40).

Myślę, że Marek Hłasko odnajdywał w tego typu sytuacjach to, co było mu potrzebne: szczere bycie $z$ innymi, akurat $\mathrm{w}$ tym przypadku tak samo jak on obcymi. To oczywiście tylko moja intuicja, wypowiadana na podstawie własnych doświadczeń pobytu w Irlandii, w której pub to prawdziwa instytucja kultury. Podobnie jak Hłasko, świetnie się czułem w tych miejscach, i choć tam także toczą się pewne gry, to mam wrażenie, że ludzie są tam ze sobą naprawdę...

Marcin KAFAR: Co do pubów jako „instytucji kultury” to tylko sygnalnie: miałem takie same odczucia mieszkając przez kilka lat w Szkocji - Szkoci pod tym względem sa podobni do Irlandczyków. Zreszta, puby generalnie sprzyjaja uruchamianiu tkwiących w nas pokładów wspólnotowości.

A teraz już całkiem poważnie: ja szczególną uwagę zwróciłem na te listy, które Hłasko pisał do matki; matka jawi się tam jako swego rodzaju opoka, oś świata, który sam w sobie jest płynny, nie do opanowania; przypomina galaretę, w która jak człowiek zbyt głęboko wpadnie, to trudno jest mu się $z$ niej wydostać. Matka była dla Hłaski centralnym punktem odniesienia zarówno w sprawach codziennych, jak i niecodziennych. $Z$ drugiej strony, $z$ tych listów, które czytałem, wyłania się człowiek usilnie potrzebujący bliskości innych ludzi, sa to jednak zawsze ludzie wybrani. Prócz matki, a właściwie "Matki” powraca w Hłaskowskich listach motyw „Kobiety”, która zawsze wydaje się być ta jedyną. Jest taki list z 1952 roku, gdzie Hłasko pisze: „Mamusiu. Ja nigdy w życiu nie przeżywałem tego, co teraz. Wiem, że byłem złym dzieckiem i tak dalej. Ale to by się wszystko dało naprawić. Mam teraz możność dostać jedna, druga i nawet trzecia pracę, a naprawdę nic nie mogę robić. Ręce mi się trzęsą, w ogóle coś się ze mna dzieje. Nie mogę spać, nie wiem co mam robić. Ta dziewczyna też płacze i nie wiem jak to się w ogóle skończy. Tu ja, a tu znowu 
matka i dziecko, a przecież to wszystko moja wina. Ja ją bardzo kocham, Mamo, i dlaczego kiedy naprawdę chciałem żyć jak człowiek, to mi się tak strasznie wszystko skomplikowało? Nie mam takiej sekundy wolnej, w której bym nie myślał o niej. Nie mogę sobie zatrzeć tego wspomnienia i wiem, że to będzie mnie prześladować. A ja nie moge sobie dać rady. I to, że jestem sam, Mamo, że nie mam do kogo iść. To jest straszne Mamo. Nie mogę naprawdę iść w tej chwili do pracy - nie mam siły. I wiem, że nikt mi nie może pomóc. To mnie zabija" (Stankiewicz-Podhorecka 1994: 54). To jest fragment, który mówi o konsekwencjach spotkania przez Hłaskę dawnej koleżanki, Wandy. Później napisał opowiadanie...

\section{Michał RYDLEWSKI: ...Pamiętasz, Wanda?}

Marcin KAFAR: Tak, i to jest właśnie ukazanie tej sytuacji. W tym fragmencie, bo sam list jest dużo dłuższy, widać jak na dłoni dwie kolaborujące ze sobą siły - Kobietę-Matkę i Kobietę-Kochankę, które łączą w jedno to, co ziemskie $z$ tym, co metafizyczne. Jeśli dodamy do tego relację człowiek - Bóg..., no właśnie, w istocie dotykamy tutaj, według mnie, sfery doświadczeń mocno autentycznych, choć wiem, że ty, Michale, nie masz zbyt dużego zaufania do tego słowa...

Michał RYDLEWSKI: Faktycznie, to dla mnie bardzo problematyczna kwestia, uwypuklajacca kontekst związku literatury i życia pisarza. Problem moim zdaniem polega na tym, czy zawsze da się wyznaczyć granice pomiędzy „życiem” jako ta częścia człowieka nie uwikłana w świat tekstowy a światem tekstowym jako miejscem autokreacji? Pewne przywołane wyżej fragmenty listów moga sugerować, że jest na to szansa, ale $z$ drugiej strony przypomina mi się wypowiedź jednego $z$ niewielu przyjaciół Marka Hłaski z Ameryki, Marka Nizińskiego, który tak oto opisywał Hłaskę na rok przed jego śmiercią: „(...) doszedł do stanu, kiedy się panicznie bał kogoś lub coś polubić, pokochać, by nie przeżywać po raz nie wiadomo który goryczy rozstania i chwil bezsilnej samotności. Stał się wtedy przez siebie stworzonym bufonem, ranił ludzi pierwszy, zadawał niezasłużone ciosy i przeżywał cierpki smak tych sytuacji sam, wyłaczając na tygodnie telefon. Pił. Wszyscy się od Marka powoli odsuwali, zostawiając go gdzieś na boku, nie próbując go choć trochę zrozumieć" (Stanisławczyk 1998: 120-121). Pytanie, co nim powodowało w tym okrucieństwie do innych i samego siebie? Myślę, że wiele listów Marka Hłaski, szczególnie tych pisanych do kobiet jego życia, w tym matki, żony i kobiet, z którymi był związany, pokazują człowieka tak wrażliwego, iż nieomal pozbawionego skóry, ponadto człowieka chyba rozczarowanego 
życiem, mającego jakieś poczucie i przeczucie klęski... Może $z$ tego właśnie względu musiał przywdziewać pewne kostiumy? Może to one go chroniły? Tak przynajmniej uważał. Wchodzę tutaj jednak już na grunt, na którym nie czuję się najlepiej...

Marcin KAFAR: Myśmy w zasadniczej części rozmowy skupili się na „prawdziwym zmyśleniu”, na tym, co dzieje się w literaturze dzięki „prawdziwemu zmyśleniu”, skoncentrowaliśmy się też na tym, jak „prawdziwe zmyślenie” ma się do tego, co pisane, mówione i przeżywane. Teraz okazuje się, że nie ma tu równomiernie rozłożonych proporcji. Punkt ciężkości położony jest na to, co przeżywane, na żywe doświadczenie życiowe. Wniosek? Może literatura jest ważna, ale nie jestem przekonany, że w kluczowych momentach życia zawsze bywa najważniejsza. Ostatnie akcenty naszej rozmowy prowadzą mnie gdzieś w tę stronę...

Michał RYDLEWSKI: To ciekawe, że rozmowę zaczęliśmy od pewnej fiksacji na temat „prawdziwego zmyślenia”, na temat tego, co jest wymyślone, a na końcu dochodzimy do tego, że najważniejsza rzecza jest to, co wykracza poza „prawdziwe zmyślenie”...

Marcin KAFAR: Zgadza się.

Michał RYDLEWSKI: A zatem doszliśmy do rzeczy chyba nawet przez nas na początku niezamierzonych...

Marcin KAFAR: To prawda, Michale. Sądzę, że jednocześnie jest to dobry moment na zaplanowanie kolejnego spotkania, tym razem może pod hasłem: "Prawdziwe zmyślenie" zrekapitulowane”?

Dziękuję ci za rozmowę...

Michał RYDLEWSKI: Ja również ci dziękuję za inspirującą wymianę myśli i za spotkanie...

\section{Bibliografia}

Atak na granice...

2011 Atak na granice autora. Z Danielem Galera rozmawia Daniela Birman, „Literatura na Świecie”, nr 1-2, s. 340-345.

Banks M.

2011 "The connection exists". Hermeneutics and authority in Paul Auster's fictional worlds, [w:] S. Ciocia, J.A. González (red.), The inventions of illusions. International perspectives on Paul Auster, s. 149-172. 
Baranowska M.

2011 To jest wasze życie. Być soba $w$ chorobie przewlekłej, posł. J. Szczęsna, Wołowiec.

Badź wierny sobie...

Badź wierny sobie... Rozmowa z Markiem Hłasko w audycji „Muzyka i aktualności”, emisja 14.02.1958 Polskie Radio, zapis rozmowy znajduje się [w:] Hłasko nieznany, szkic wstępny i oprac. Beachy S. P. Wasilewski, Kraków, 1991, s. 189-190.

2005 Who is the real JT LeRoy? A search for the true identity of a great literary hustler, „New York Magazine”, październik, (tekst dostępny pod adresem: http://nymag.com/nymetro/news/ people/features / 14718/; data dostępu: 11.12.2015).

Benderson B.

2005 wyimek $z$ Letters to the editor, „New York Magazine”, 25 października, (tekst dostępny pod adresem: http://nymag.com/ nymag/letters /14794/; data dostępu: 12.12.2015).

Big Think interview...

2009 Big Think interview with Paul Auster, wywiad z Paulem Austerem przeprowadzony przez Allena Austina, (transkrypcja dostępna pod adresem: http://bigthink.com/videos/big-thinkinterview-with-paul-auster; data dostępu:19.09.2015).

Campbell J.

1994 Potega mitu. Rozmowy Billa Moyersa z Josephem Campbellem, oprac. B.S. Flowers, przeł. I. Kania, Kraków.

1997 Bohater o tysiacu twarzy, przeł. A. Jankowski, konsultacja merytoryczna W.J. Burszta, Poznan.

2004 Mityczny obraz, przeł. A. Przybysławski, T. Sieczkowski, Warszawa. Chénetier M.

1995 Paul Auster's pseudonimous world, [w:] D. Barone (red.), Beyond the red notebook. Essays on Paul Auster, Philadelphia, s. 34-43.

Csikszentmihàlyi $\mathrm{M}$.

2005 Przepływ-jak poprawić jakość życia. Psychologia optymalnego doświadczenia, przeł. M. Wajda-Kacmajor, Taszów.

Chmielewski A.

1993 Spotkania z Markiem Hłasko (1), „Odra”, nr 7-8, s. 62-69.

Eco U.

1995 Sześć przechadzek po lesie fikcji, przeł. J. Jarniewicz, Kraków. Eliade M.

1966 Traktat o historii religii, przeł. J.W. Kowalski, wstęp L. Kołakowski, posł. S. Tokarski, Warszawa.

1998 Mit wiecznego powrotu, przeł. K. Kocjan, Warszawa. Frank A.W.

1997 Enacting illness stories. When, what, and why, [w:] H.L. Nelson (red.), Stories and their limits. Narrative approaches to bioethics, London-New York, s. 31-49. 
Guriewicz A.

1976 Kategorie kultury średniowiecznej, przeł. J. Dancygier, Warszawa. Hłasko M.

1989 Okno [w:] M. Hłasko, Opowiadania, Warszawa, s. 122-124.

1993a Sowa córka piekarza, Warszawa.

1993b Drugie zabicie psa, Warszawa.

1994 Piekkni dwudziestoletni, Warszawa.

Jackowski A.

2007 Na skróty. Posłowie, „Konteksty”, t. 61, nr 1, s. 148-160.

Knoop S.

2008 Girl boy girl. How I became JT Leroy, New York.

Markiewka T.

2012 Literatura, rzeczywistość, interpretacja, „Teksty Drugie”, nr 1-2, s. 280-293.

Nowak T.

1968 A jak królem, a jak katem będziesz, Warszawa.

1976 Półbaśnie, Warszawa.

Padoł E.

2015 Szczepan Twardoch: w cieniu przodków, na ich kościach, (tekst dostepny pod adresem: http://wiadomosci.onet.pl/tylko-w-onecie/szczepan-twardoch-w-cieniu-przodkow-na-ich-kosciach-wywiad/93k8cv; data dostępu: 11.12.2015).

Rydlewski M.

2015 Opozycja jako kategoria kulturowa w perspektywie poznańskiej szkoły kulturoznawczej (opozycja jako wynalazek oraz element gramatyki kultury europejskiej) [w:] M. Banach (red.), Opozycje w kulturze, Poznań (tekst w druku).

Sendyka R.

2014 Od kultury ja do kultury siebie. O zwrotnych formach $w$ projektach tożsamościowych, Kraków.

Stanisławczyk B.

1998 Miłosne gry Marka Hłaski, Warszawa.

Stankiewicz-Podhorecka T.

1994 Listy Marka Hłaski, Warszawa.

Simonsen R.R.

2009 Even or(r) odd. The game of narration in Paul Auster's Oracle night, „American Studies in Scandinavia”, t. 41, nr 1, s. 83-107.

Śmierć samotnego...

1991 Śmierć samotnego „mitomana”. Rozmowa z Maria Hłasko, pierwodruk: „Student”, nr 3, 1986; przedruk znajduje się [w:] Hłasko nieznany, szkic wstępny i oprac. P. Wasilewski, Kraków, s. 209-215.

Wilde O.

1997 [1913] The critic as artist. With some remarks upon the importance of doing nothing, [w:] O. Wilde, Intentions, s. 26-59 (tekst do- 
stępny pod adresem: http://s3.amazonaws.com/manybooks_ pdf_new/wildeoscetext97ntntn10?AWSAccessKeyId=AKIAITZP2AAM27ZGISNQ\&Expires $=1452071034 \&$ Signature=ipiotvum7BREavrZhWDxw03YFhk\%3D; data dostępu: 13.12.2015).

Wróblewski M.

2012 „Prawdziwe zmyślenie” $w$ dobie refleksyjnej nowoczesności. Przypadek Jerzego Kosinskiego (niepublikowany referat wygłoszony podczas konferencji pt. Autobiografia-biografia-narracja. Perspektywy biograficzne $w$ praktyce badawczej/Autobiography - biography - narration. Biographical perspectives in research practice, Łódź 29-30 maja).

\section{Pozostałe źródła}

Alpy, film fabularny w reż. Giorgiosa Lanthimosa, scenariusz Giorgos Lanthimos, Efthymis Filippou, 2011.

Serce jest zdradliwe, film dokumentalny z serii: „Oszuści” (org. „Impostors"), prod. CMJ Productions II inc.

$Z$ nimi żyłem, $z$ nimi piłem, ich kochałem - Marek Hłasko, film dokumentalny w reż. J. Sosińskiego, scenariusz J. Ossowski, J. Sosiński, Warszawa 1999. 